\title{
THE FRIENDS OF THE WEST COUNTRY ASSOCIATION V. MiNISTER OF FISHERIES AND OCEANS DIRECTOR, MaRINE PROGRAMS, CANAdIAN COAST GUARD' (F.C.T.D.) — THE "SUNPINE DECISION"
}

\section{ARLENE J. KWASNIAK*}

\section{INTRODUCTION}

Federal and provincial regulators, regulated industry, and environmental and other public interest groups awaited this Federal Court Trial Division decision with nervous anticipation. The case concerns what federal regulators must include in an environmental assessment under the Canadian Environmental Assessment Act $^{2}$ (CEAA) and its regulations.

Such environmental assessment, or EA, cuts deep to many controversial and sometimes heated environmental, political and social issues. Those who champion provincial rights and devolution of federal powers to provinces see strong mandatory federal EA requirements as intrusions on and roadblocks to, provincial autonomy. Those, often from regulated industry, who favour a view of harmonization of provincial and federal EA processes that would in effect eliminate one level of assessment see mandatory extensive federal EA as impeding the process reduction. Those who advocate public health and environmental quality want governments who authorize projects that can potentially damage health or environment to fully and broadly assess potential effects. When both the federal government and provincial government have a regulatory or other close interest in a proposed project, public interest groups want to ensure that the assessment is broad enough so that each level can act on complete information when making its decision on the proposal. Federal regulators also have a stake in federal EA issues. They often operate under tight budgets and are sometimes plagued by uncertainty over political and even perhaps constitutional or other legal boundaries on federal EA and need to know their legal obligations when conducting an EA process.

The Sunpine decision clarified some aspects of legal requirements under the CEAA. As detailed later in this note, the Court interpreted the CEAA to require, in certain cases, a broad assessment scope potentially including environmental assessment of the undertakings related to the project. The decision gives reason to please environmental, health and other public interest groups. Although the decision may worry industry in that it will lead to more thorough federal EA, it should at least clarify the process so that project proponents, as well as federal regulators, can do it right the first time, and not be subject to prolonged, costly legal proceedings. 


\section{THE FACTS}

The federal Navigable Waters Protection $\mathrm{Act}^{3}$ requires federal approval in order to construct a bridge over navigable water. Sunpine Forest Products Ltd. (Sunpine) applied for two approvals under that Act, one to construct a bridge over Prairie Creek and one to construct a bridge over Ram River, both navigable waters, in connection with Sunpine's forestry operations in central/western Alberta. Regulations under the CEAA triggered a requirement for an environmental assessment to precede consideration of any such approval. ${ }^{4}$ The Sunpine assessment process resulted in two Screening Environmental Assessment Reports (Reports), one for each approval application. The respondents considered the Reports, and finding no likely significant adverse effects, issued the approvals to build the bridges. Shortly thereafter, Friends of the West Country Association (Friends) applied for judicial review. Although Friends sought judicial review on a number of grounds, this note focuses on Friends' request that the Court declare the Reports and approvals invalid on the ground that the respondents failed to comply with statutory duties under the CEAA.

\section{STANDARD OF REVIEW}

The standard of review that a court may use when considering whether or not a statutory delegate complied with a statutory duty can be crucial to the decision's outcome. If the issue before the court is a question of law, the correct standard of review is whether the statutory delegate's decision or action was right in law. However, if the issue is a question of the exercise of discretion or judgment, then the correct standard of review is whether the statutory delegate's action was patently unreasonable or not. ${ }^{5}$ Obviously the latter standard gives the court much less latitude in its review than the former. The respondents urged the Federal Court to consider issues relevant to the CEAA EA duties to be questions of discretion or judgment. The applicant urged the Court to consider them to be questions of law. Gibson J. split his determinations. He found the CEAA duty with respect to determining scope of project to be a matter of discretion or judgment and subject to the patently unreasonable standard. However, he found the CEAA duties which involved determining scope of assessment and consideration of cumulative effects to raise questions of law and to be subject to the more rigorous correctness standard.

\section{Section 15: Scope of Project VS. Scope of AsSessment}

Scope of project concerns what components of a proposed development should be considered as the "project" subject to the CEAA EA process. By contrast, scope of assessment concerns what environmental effects and impacts are to be assessed in an EA.

\section{R.S.C. 1985 , c. N-22, s. 5.}

SOR/94-636.

Supra note 1 at para. 28. Gibson J., in the Sunpine Decision referred to Canada (Attorney General) v. Mossop, [1993] 1 S.C.R. 554 at 577-78 (ibid. at para. 26) and Union of Nova Scotia Indians v. Canada (Attorney General), [1997] 1 F.C. 325 (T.D.) (ibid. at para. 27). 


\section{A. SCOPE OF Project}

In the circumstances of the case, s. 15 of the CEAA required the "Responsible Authority," allegedly the respondents, to determine the scope of the project. In brief, under the CEAA, the Responsible Authority (RA) is the person charged with administering many of the CEAA EA provisions by virtue of also having independent decision-making power regarding a proposed project, such as whether or not to issue a permit under federal legislation or to lend federal funds. ${ }^{6}$ The respondents had scoped each project to include only the bridge, associated approaches and works. The issues for the Court were whether the CEAA required them to include in each project the logging road attached to the bridge and whether the two bridges constituted one or two projects.

The CEAA does not provide direction for RAs in determining scope of project. However, the Canadian Environmental Assessment Act Responsible Authorities Guide (Guide), a non-regulatory policy document prepared under CEAA, does provide guidance. ${ }^{7}$ It states that " $[\mathrm{t}] \mathrm{o}$ ensure consistency in scope of project determinations, RAs should consider applying the "principle project/accessory test."' Under this test the RA first includes in scope the principle project, that is, the principle physical work that triggered the CEAA. Then the RA determines which physical works or activities, if any, are "accessory" to the principle project. "Accessory" means that the principle project could not proceed without such work or activity and the decision to undertake the principle project makes the decision to undertake such work or activity inevitable. ${ }^{8}$

Gibson J. found the "principle of independent utility" to be reflected in the sections of the Guide dealing with scope. This principle of independent utility is derived from U.S. law and holds that in determining scope "the independent utility of a proposed work or project appears to constitute a critical factor." ${ }^{9}$ In this regard Gibson J. noted that "[b]ridges are singularly useless structures when taken in the abstract. They serve no useful purpose but to facilitate getting from some place to some place else over an impediment, usually water, that separates the places." ${ }^{10}$ However, noting that, the CEAA gives the Responsible Authority discretion to determine scope of project and whether to consider the two applications as one or more than one project. Gibson J. stated that although he might have determined the matter differently, he could find no reviewable error ${ }^{11}$ and would not interfere with the statutory delegates' exercise of discretion.

See CEAA, supra note 2 at s. 2 for the definition of "responsible authority" and ss. 5 and 11 . An issue in the case was whether the respondents were in fact and law appropriate Responsible Authorities for the purposes of CEAA and for issuing approvals under the Navigable Waters Protection Act (supra note 3 at s. 1). Without determining the matter, the Court proceeded on other issues.

7 Canada, Ministry of Supply and Services, Cat. No. EN106-25/1-1994E, (November 1994). Referred to in Sunpine, supra note 1 at para. 34.

Ibid. at 18, referred to in Sunpine, ibid. at para. 36.

Sunpine, ibid. at para. 31.

Ibid. at para. 31.

Ibid. at para. 47. In other words, he could find no patent unreasonableness. 
But, in the words of the Court "...that is not the end of the matter."12

\section{B. SCOPE OF ASSESSMENT}

In exercising their statutory duties to determine scope of the assessments, the respondents limited the scope for both EA's to the scope of the projects, namely the bridges and directly associated approaches and works. The issue for the Court was whether the respondents should have also included assessment of the roads to be constructed extending from the bridges. Gibson $\mathrm{J}$. found this to be a question of law and thus his inquiry was whether the respondents correctly exercised their statutory duties in determining scope of assessment, rather than whether or not they were patently unreasonable in determining scope.

Gibson J. noted that s. 15(3) of the CEAA states that where a project is in relation to a physical work, the environmental assessment:

...shall be conducted in respect of every construction, operation, modification, decommissioning, abandonment and other undertaking in relation to that physical work that is proposed by the proponent....

He found s. 15(3) to be mandatory in that it gives the RA no discretion, and he added that it reflects the principle of independent utility. ${ }^{13}$ Gibson J. determined that the logging roads were constructions or undertakings in relation to the physical works the bridges - and therefore the CEAA required the respondents to include them in the scope of the EAs. They had not and accordingly failed to comply with the law.

\section{SECTION 16: Cumulative EFFECTS}

Subsection 16(1) of CEAA provides that every screening:

... shall include consideration of ... the environmental effects of the project, including ... any cumulative effects that are likely to result from the project in combination with other projects or activities that have been or will be carried out...

Gibson J. noted that not only were the roads likely to be carried out, but were already carried out to a substantial degree. Again applying the legal standard of correctness, he found s. 16(1) of the CEAA to be mandatory and accordingly found that the respondents erred in not including consideration of the roads in the screening reports. Gibson J. later intimated that on a generous reading of the CEAA since "the proponents proposed [that] forestry operations in the West Country will also be carried out," ${ }^{14}$ the CEAA would require the EA to extend to forestry operations. ${ }^{15}$ 
Based on the evidence and his analysis, Gibson J. stated:

... in the absence of a direct constitutional challenge to those provisions, and there is none here, I conclude that the environmental assessments conducted were deficient ... [and] [t]hese deficiencies constituted errors of law in the essential statutory preliminary steps to the issuance of the approvals under the NWPA. ${ }^{16}$

He set aside the approvals and referred the EA Reports back to the Responsible Authority for redetermination in a manner consistent with the CEAA.

\section{IMPACT OF CASE?}

\section{A. Fear of Overturning Existing Approvals, RENDERING HARMONIZATION USELESS AND ENDLESS EXTENSION OF EA REQUIREMENTS}

The Alberta government has heavily lobbied Ottawa to appeal, which must be done by September 30. Minister Ty Lund reportedly called the decision "ludicrous" and wants it overturned. ${ }^{17}$ Alberta Environmental Protection spokesman Michael Lohner reportedly said that if it is not appealed "...we might as well walk away from the harmonization process ... It's been a waste of time." 18 Critics worry that the decision will lead to limitless assessments and say that it could affect "millions of dollars of development from public transit in British Columbia to forestry in Manitoba to the Voisey's Bay project in Labrador." ${ }^{19}$ On the other hand, public interest environmental group representatives like Sam Gunsch of the Canadian Parks and Wilderness Society praise the case. Gunsch says "the decision merely upholds federal environmental law." 20

\section{OVerturning of EXisting ApProvals?}

If the decision stands will it lead to quashing of numerous approvals since they were based on environmental assessments that did not comply with the law? Perhaps, depending on how flush and aggressive is the environmental community. Even if this is the effect, it only means that project proposals must be re-assessed in order to legally consider re-issuing required approvals. What are the chances that on a valid assessment an already completed project will not be issued an approval? It is hard to speculate, but it should noted that under the CEAA, even if a decision-making authority determines that a project will have significant environmental effects, he or she may still allow the project to go ahead if it is "justified in the circumstances." ${ }^{21}$ I suggest that in today's political climate a project already constructed and in operation will lend considerable

Ibid. at paras. 55,56 .

R. Henderson, "Lund lobbies feds to fight bridge ruling" The Edmonton Journal (13 August 1998) A5.

B. Weber, National General News, (18:45 EST, 12 August 1998).

Ibid.

Ibid.

CEAA, supra note 2 at s. 37(1)(a)(iii). 
support towards justification in the circumstances. Nevertheless, if a valid EA results in truly dire environmental effects the project probably should not be approved, even if in operation.

\section{RENDER HARMONIZATION USELESS?}

If the decision stands will it make the work on harmonization to date a waste of time? I cannot see how. The Sunpine case simply states what is required under federal law to carry out a valid environmental assessment. This does not affect the CanadaWide Accord on Environmental Harmonization (Accord) ${ }^{22}$ and sub-agreement on environmental assessment. Moreover, harmonization was not at issue in the case since the Province did not require an environmental impact assessment report under the Environmental Protection and Enhancement $\mathrm{Act}^{23}$ that could have been conducted in conjunction with the federal assessment. ${ }^{24}$ Indeed, even if there had been a joint federal-provincial assessment process the case would not render harmonization discussions a waste of time. There is nothing in the current CEAA, the Accord or the environmental assessment sub-agreement that would validate, in effect, the stripping down and removal of the substantive legislative mandates of one level of government so that only less demanding mandates of the other level apply. ${ }^{25}$ Further, the CanadaAlberta Agreement for Environmental Assessment Cooperation, in effect during the Sunpine approval processes, states that a cooperative environmental assessment "... shall meet the legal and operational requirements of both governments." 26 Accordingly, if the CEAA requires a more encompassing substantive EA than provincial legislation, harmonization would require the broader requirements to be included in the harmonized process.

\section{Limitlessly Proliferate ASSessable Effects?}

Is there any end to the kinds of environmental effects that a RA must include? Regarding scope of assessment it must be remembered that s. 15(3) of the CEAA only requires consideration of other undertakings in relation to a physical work proposed by the proponent and not everything under the sun. Further, the Sunpine case interpreted this mandatory requirement to reflect the principle of independent utility. This "but for" test should further limit mandatory assessment to the proponent's proposals that would not be carried out but for the project.

$23 \quad$ S.A. 1992 , c. E-13.3.

24 Advice to the writer from various sources, including Dr. Martha Kostuch, who is associated with the applicant, Friends of the West Country Association. Dr. Kostuch advised that she unsuccessfully requested formal environmental assessment review under the Environmental Protection and Enhancement Act. She also advised that she obtained all available relevant documents related to any review of the Sunpine proposals through the process under the Freedom of Information and Protection of Privacy Act (S.A. 1994, c. F-18.5) or otherwise.

25 This could be done, of course, by legislative change to accommodate the Accord.

26 Canada-Alberta Agreement for Environmental Assessment Cooperation (6 August 1993 to 6 August 1998) at 3. 
Regarding cumulative effects, s. 16(1) of the CEAA makes it clear that such effects must be assessed, but gives no guidance to scoping cumulative effects as to geographical limits, ecological limits or limits on time, whether past or future. The RA Guide dedicates fifteen pages to cumulative effects, but, given the generality of the discussion, it will in many cases require a qualitative approach. ${ }^{27}$ Assuming, along with Gibson J. in the Sunpine decision, whether or not something is a cumulative effect is a question of law and not of discretion, RAs are put into the precarious position of having to be right in determining cumulative effects or else subject to judicial review on the legal standard. This may well lead to precaution on the part of RAs and to broadly based scoping of cumulative effects.

It should be noted that Canada is not alone in having legislation that requires assessment of broad-based cumulative effects. Cumulative effects also must be assessed under the U.S. National Environmental Policy Act ${ }^{28}$ (NEPA) President's Council on Environmental Quality (CEQ) regulations which defines a "cumulative impact" as:

the impact on the environment which results from the incremental impact of the action when added to other past, present and reasonably foreseeable future actions regardless of what agency (Federal or non-Federal) or person undertakes such other actions. Cumulative impacts can result from individually minor but collectively significant actions taking place over a period of time. ${ }^{29}$

In response to uncertainty over the application of the term "cumulative impacts" in 1997 the CEQ prepared a handbook for practitioners. ${ }^{30}$ This handbook of over fiftynine pages provides considerable detail to guide those administering or preparing NEPA EAs so that they may comply with the legislation and therefore not likely be susceptible to judicial review for this reason. Perhaps Canada should follow suit and provide detailed regulatory guidance to RAs and other stakeholders.

\section{B. Constitutional Limitations on Scoping?}

Finally, it is intriguing to note that in making his decision Gibson J. prefaced his conclusions by saying "in the absence of a direct constitutional challenge to these provisions." ${ }^{31}$ Perhaps the yet to be litigated issues are whether there are constitutional limitations on what a Responsible Authority may include in an EA. For example, are there valid arguments to be made that the federal government must limit its EA inquiry to those matters under federal constitutional jurisdiction? Would it make a difference whether the federal EA is required where the CEAA is triggered because federal lands or funds are involved rather than merely a decision-making power under substantive federal legislation? Although it is not clear how these arguments will be made, it will be no surprise to see them as the subject of future litigation. 